\title{
PEMBIAYAAN UMKM, KINERJA BANK SYARIAH DAN PERTUMBUHAN EKONOMI DI INDONESIA
}

\author{
Iwan Setiawan \\ Jurusan Akuntansi, Politeknik Negeri Bandung \\ Email: iwan.setiawan@polban.ac.id
}

\begin{abstract}
Sharia banks have an important role to do with the development of MSMEs and the economy in Indonesia. The share of sharia bank financing in MSMEs decreased beyond the minimum limit set. This study aims to look at the role of MSME financing on the performance of Sharia banks and economic growth in Indonesia. The study used monthly data for the period 2016-2019 with the two stage least square (TSLS) analysis method. The results of this study revealed that financing in MSMEs contributes greatly to the improvement of the performance (ROA) of Sharia banks. The financing of MSMEs of Sharia banks does not contribute directly to economic growth. The contribution of MSME financing to economic growth occurs through the role of profit (ROA) of Sharia banks. There is a two-way relationship and mutual influence between sharia bank profits and economic growth. The role of economic growth towards bank profits is greater than the role of sharia banks in economic growth. It is important to pay attention to the portion and quality of financing in MSMEs that can improve the performance of Sharia banks and at the same time boost economic growth in Indonesia.
\end{abstract}

Keywords: MSMEs, ROA, Sharia Banks, Economic Growth

\begin{abstract}
Abstrak
Bank syariah beperan penting terhadap perkembangan UMKM dan perekonomian di Indonesia. Porsi pembiayaan bank syariah pada UMKM mengalami penurunan melampaui batas minimal yang ditetapkan. Penelian ini bertujuan untuk melihat peran pembiayaan UMKM terhadap kinerja bank syariah dan pertumbuhan ekonomi di Indonesia. Penelitian menggunakan data bulanan periode 2016-2019 dengan metode analisis Two Stage Least Square (TSLS). Hasil penelitian ini mengungkapkan bahwa pembiayaan pada UMKM memberikan kontribusi yang besar terhadap peningkatan kinerja (ROA) bank syariah. Pembiayaan UMKM bank syariah tidak memberi kontribusi terhadap pertumbuhan ekonomi secara langsung. Kontribusi pembiayaan UMKM terhadap pertumbuhan ekonomi terjadi melalui peran keuntungan (ROA) bank syariah. Terdapat hubungan dua arah dan saling mempengaruhi antara keuntungan bank syariah dengan pertumbuhan ekonomi. Peran pertumbuhan ekonomi terhadap keuntungan bank lebih besar dari pada peran keuntungan bank syariah terhadap pertumbuhan ekonomi. Sangat penting memperhatikan porsi dan kualitas pembiayaan
\end{abstract}


264 | Iwan Setiawan, PeMbiayaAN UMKM, KINERJA BANK SYARIAH DAN PERTUMBUHAN......

pada UMKM yang dapat meningkatkan kinerja bank syariah dan sekaligus mendorong pertumbuhan ekonomi di Indonesia.

Kata kunci: UMKM, ROA, Bank Syariah, Pertumbuhan Ekonomi

\section{Dasar Pemikiran}

Tahun 2020 Indonesia mengalami pandemi virus Corona (Covid-19). Pandemi memberikan dampak buruk bagi kesehatan dan kondisi perekonomian. Upaya menangani dampak buruk bagi kesehatan berakibat pada terganggunya aktivitas ekonomi. Usaha Mikro, Kecil dan menengah (UMKM) adalah sektor usaha yang diprediksi merasakan dampak buruk dari berbagai kebijakan untuk menangani pandemi Covid-19. UMKM adalah sektor ekonomi yang mampu menciptakan 97,02\% lapangan kerja, memberikan kontribusi sebesar $57.08 \%$ terhadap produk domestik bruto dan 53,24\% terhadap pembentukan investasi di Indonesia (Darsono \& Darwanto, 2019). UMKM juga memiliki daya adaptasi yang tinggi dan mampu bertahan dalam kondisi krisis ekonomi (Kara, 2013). Terpuruknya aktivitas UMKM akibat pandemik Covid-19 akan membawa dampak buruk bagi perekonomian secara keseluruhan,

UMKM adalah sektor usaha yang memiliki potensi besar mendukung perkembangan ekonomi secara makro, tapi memiliki kendala dari sisi internal maupun eksternal. Persoalan yang dihadapi UMKM pada berbagai daerah seragam terkait keterbatasan modal kerja, rendahnya kualitas SDM, kualitas produk dan produktivitas serta terbatasnya penguasaan ilmu pengetahuan dan teknologi (Lubis, 2016). Kemampuan manajerial dan aspek permodalan menjadi masalah utama, berdampak terhadap terbatasnya akses dana yang bisa diperoleh dari lembaga keuangan. Kendala akses pembiayaan dari lembaga keuangan bagi UMKM diatasi oleh Bank Indonesia melalui Peraturan BI No. 14/22/2012. UMKM memperoleh bantuan teknis dan kredit/pembiayaan 20\% minimum dari total yang kredit/pembiayaan yang disalurkan bank umum sejak tahun 2018.

Persoalan perekonomian yang timbul akibat wabah covid-19 bisa diselesaikan melalui ekonomi syariah. Persoalan ekonomi yang terjadi kapan dan dimana saja bisa diselesaikan dengan ekonomi Islam. Bank syariah adalah salah satu lembaga keuangan 
yang merupakan bagian dari ekonomi syariah. Bank syariah menyalurkan pembiayaan pada berbagai sektor ekonomi, termasuk untuk UMKM(Nurhidayat, 2020). UMKM adalah sektor usaha yang berperan dominan terhadap meningkatnya industri halal di dunia. Pembiayaan syariah menjadi sangat penting untuk mendorong peningkatan UMKM halal. Kendala yang dihadapi untuk mengoptimalkan pembiayaan syariah adalah rendahnya kesadaran, pemahaman dan niat yang masih terbatas dari pelaku UMKM yang untuk bekerja sama dengan lembaga keuangan syariah (Qoyum \& Fauziyyah, 2019).

Dalam periode 2016-2020 rata-rata pertumbuhan pembiayaan untuk UMKM tumbuh sebesar 5,9\% pert tahun. Pembiayaan UMKM untuk tujuan modal kerja dan investasi masing-masing tumbuh sebesar $4,85 \%$ dan $8,15 \%$ per tahun. Walaupun pembiayaan bank syariah untuk UMKM mengalami peningkatan, namun porsi pembiayaan UMKM terhadap keseluruhan pembiayaan yang dilakukan bank syariah mengalami trend penurunan. Pata tahun 2016, rasio alokasi pembiayaan bank syariah terhadap UMKM sebesar 21,99\%, pada tahun 2019 menurun menjadi 18,68\%. Sejak tahun 2018 rasio pembiayaan bank syariah pada UMKM berada di bawah 20\%, tidak memenuhi aturan minimum sesuai dengan ketetapan Bank Indonesia (gambar 1).

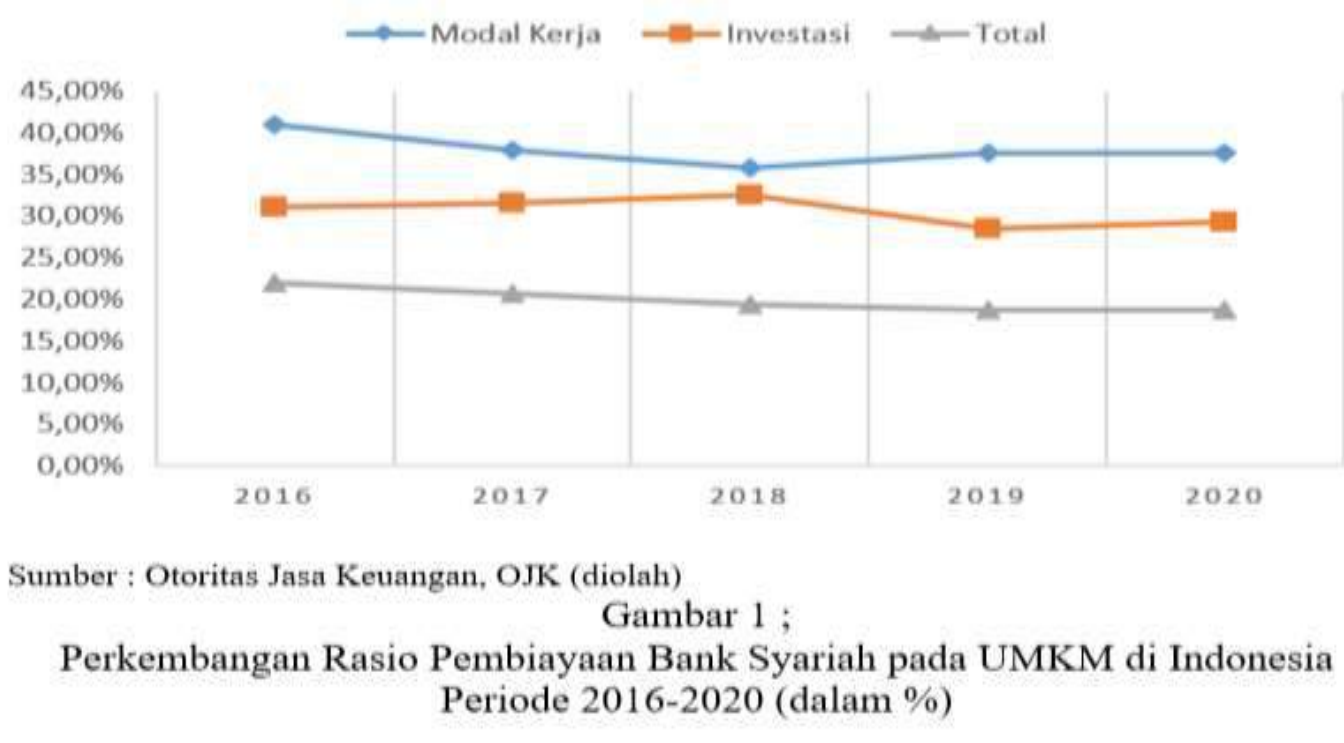




\section{6 | Iwan Setiawan, PEMBIAYAan UMKM, KINERJA BANK SYARIAH DAN PERTUMBUHAN......}

UMKM merupakan sektor usaha yang berperan penting perkembangan ekonomi secara makro dan bagi peningkatan kinerja Bank Syariah. Rendahnya porsi pembiayaan bank syariah pada UMKM akan membawa implikasi ekonomi dan hukum yang harus diantisipasi oleh pihak bank. Upaya untuk mendorong jumlah dan porsi pembiayaan bank syariah didasarkan pada bukti pentingnya pembiayaan UMKM bagi perbaikan kinerja bank syariah secara internal dan peningkatan perekonomian secara makro. Berdasarkan permasalahan yang yang sudah diungkapkan, maka riset ini bertujuan untuk mengetahui 1) Seberapa besar peran pembiayaan UMKM terhadap peningkatan kinerja bank syariah 2) Seberapa besar peran pembiayaan UMKM bank syariah terhadap pertumbuhan ekonomi 3) Bagaimana hubungan antara pembiayaan UMKM, perbaikan kinerja bank syariah dan pertumbuhan ekonomi di Indonesia.

\section{Tinjauan Pustaka}

Perbankan adalah lembaga perantara keuangan, yang menjembatani pihak surplus dana dengan pihak difisit dana. Sumber dana bank dan kredit/pembiayaan memberikan kontribusi pada kinerja bank dan kontribusi pada perekonomian baik skala mikro maupun makro. Pembiayaan bank syariah dan kinerja perekonomian diprediksi memiliki hubungan yang bersifat sebab akibat. Pengembangan lembaga keuangan syariah akan berpengaruh pada pertumbuhan perekonomian baik jangka pendek maupun dalam jangka panjang. Dalam jangka panjang, perlu upaya untuk memperbaiki sistem keuangan Islam sehingga dapat mendorog aktivitas dan memperbaiki berbagai permasalahan dalam perekonomian. Pada prinsipnya tidak ada perbedaan yang berarti antara stabilitas sistem keuangan (bank) konvesional dan syariah. Stabilitas perbankan syariah ditentukan oleh faktor khusus yang berbeda dengan faktor yang ada di perbankan konvensional. Pembiayaan, efisiensi dan pengelolaan resiko merupakan faktor penentu stabilitas pada perbankan syariah (Kasri \& Azzahra, 2020).

Kinerja bank syariah dan perekonomian ditentukan oleh berbagai faktor. Modal dan Inflasi merupakan faktor yang menentukan rentabilitas perbankan syariah. Modal, pembiayaan bank syariah, inflasi dan intrumen kebijakan moneter merupakan faktor yang mempengaruhi pertumbuhan ekonomi. Kredit perbankan konvensional dan 
pembiayaan perbankan syariah sama-sama memiliki efek positif pada aktivitas perekonomian. Peran pembiayaan bank syariah perannya tidak terlalu besar dibandingkan peran kredit perbankan konvensional terhadap pertumbuhan ekonomi (Setiawan, 2020). Penelitian lain mengungkapkan adanya hubungan dua arah antara permbiayaan bank syariah dengan pertumbuhan ekonomi. Pertumbuhan ekonomi juga dipengaruh oleh dana pihak ketiga (simpanan) pada bank syariah. Pembiayaan bank syariah memberikan kontribusi terbesar pada pertumbuhan ekonomi (El Ayyubi et al., 2018).

Peran pembiayaan syariah dikaji lewat porsi perbiayaan yang teralokasi pada masing-masing sektor ekonomi. Hasil kajian mengungkapkan bahwa pembiayaan bank syariah berperan positif dalam peningkatan aktivitas ekonomi. Peran pembiayaan bank syariah memberikan kontribusi searah pada 7 sektor sektor ekonomi, hanya sektor pertanian dan pertambangan yang memberikan kontribusi negatif pada penciptaan lapangan kerja (Setiawan, 2019). Dalam jangka pendek terdapat adanya hubungan sebab akibat antara pembiayaan perbankan syariah dan perkembangan perekonomian Indonesia. Dalam jangka panjang, variabel pembiayaan bank syariah dan instrument kebijakan moneter syariah (SWBI/SBI Syariah) memberikan kontribusi terhadap pertumbuhan ekonomi, walauun peran nya tidak terlalu besar (Setiawan, 2017).

Banyak kajian dilakukan untuk mengetahui dampak asset terhadap kinerja bank syariah. Likuiditas, pengelolaan asset dan porsi modal berpengaruh signifikan terhadap peningkatan laba bank. Modal dan kualitas asset tidak berpengaruh terhadap kemampuan bank syariah mendapat keuntungan (Sahyouni \& Wang, 2018). Pembiayaan bank syariah tersalur melalui berbagai jenis akad. Pembiayaan mudharabah dan al_qardh memberikan dampak yang berbeda terhadap potensi bank syariah memperoleh keuntungan. Pembiayaan $\mathrm{Al}$ qardh terbukti signifikan berpengaruh positif terhadap kemampuan memperoleh laba bagi bank syariah (Afkar,2017). Pembiayaan yang cocok untuk pengembangan UMKM adalah pembiayaan mudharabah muqayyadah. Prinsip pembagian keuntungan pada pembiayaan mudharabah muqayyadah menambah potensi UMKM memperoleh peningkatan pendapatan, 


\section{I Iwan Setiawan, PEMBIAYAAN UMKM, KINERJA BANK SYARIAH DAN PERTUMBUHAN......}

memperluas skala usaha dan melakukan diversifikasi (Afkar et al., 2020). Penelitian lain mengungkapkan hasil yang berbeda. Pembiayaan yang cocok untuk pengembangan UMKM adalah pembiayaan Musyarakah. Pada pembiayaan ini terdapat keadaan dan karakteristik yang memungkinkan pembiayaan dapat dimanfaatkan secara optimal oleh UMKM (Trimulato, 2017). Harus banyak ditemukan inovasi produk-produk pembiayaan bank syariah yang relevan dengan perkembangan dan kebutuhan UMKM (Zaimsyah, 2020).

Beberapa kajian mengungkap pembiayaan UMKM memberikan peran penting terhadap peningkatan kinerja pelaku UMKM dan bank syariah. Pembiayaan bank syariah memberikan pengaruh yang baik bagi kinerja dan kesejahteraan pelaku UMKM. Pengaruh positif pembiayaan terhadap kinerja UMKM berpotensi mendorong peningkatan kinerja bank syariah secara internal (Faisol, 2017). Modal bank dan pembiayaan pada sektor UMKM berpengaruh terhadap kemampuan memperoleh keuntungan bank syariah. Dalam pelaksanakan pembiayaan bank syariah dengan prinsip profit/revenue sharing, keuntungan yang diperoleh pihak bank sekaligus menggambarkan hasil keuntungan yang diperoleh pelaku usaha (Afkar, 2017). Penelitian-penelitian ini mengungkapkan bahwa pembiayaan bank syariah pada UMKM memberikan kontribusi penting bagi pengembangan UMKM dan perkembangan indutri perbankan syariah.

Pembiayaan bank syariah pada UMKM selain memberikan kontribusi bagi internal bank dan pelaku UMKM, juga memberikan peran pada perkembangan perekonomian secara makro. Jumlah tenaga kerja dan nilai investasi pada UMKM memberikan dampak pada peningkatan kontribusi sektor pendapatan nasional (GDP). Sektor UMKM perlu mendapat perhatian untuk meningkatkan kontribusinya pertumbuhan ekonomi (sektor riil) (Hamza \& Agustien, 2019). Sektor usaha mikro, kecil dan menengah (UMKM) memberikan kontribusi yang sangat besar terhadap pembentukan lapangan kerja, mendorong perekonomian dan tangguh menghadapi perubahan kondisi ekonomi yang sangat drastis (Tambunan, 2019).

Berdasarkan kajian terhadap berbagai penelitian telah dilakukan serta mengacu pada konsep teori yang mendasari fungsi intermediasi perbankan syariah serta 
dampaknya bagi internal bank, industri dan perekonomian secara maktro, maka proses penelitian yang akan dilakukan digambarkan melalui kerangka pemikiran penelitian berikut ini.
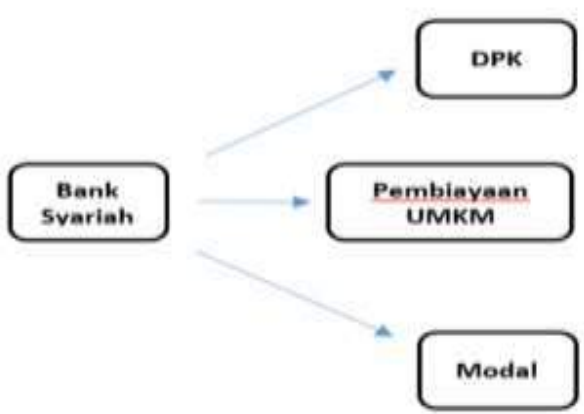

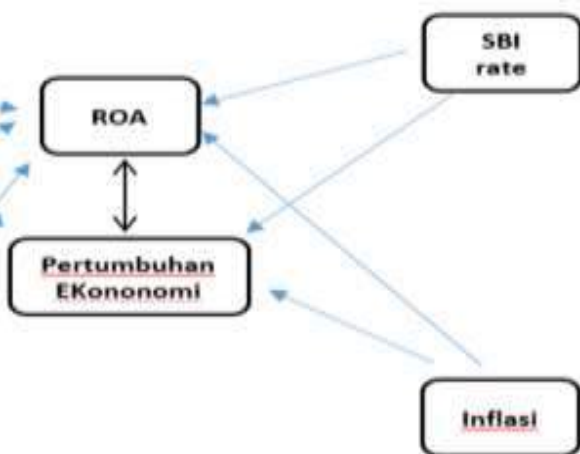

Sumber ; hasil olahan

\section{Gambar 2. Kerangka Pemikiran Penelitian}

Dasar pemikiran mencakup latar belakang atas isu atau permasalahan serta urgensi dan rasionalisasi kegiatan penelitian.Tujuan kegiatan dan rencana pemecahan masalah disajikan, termasuk tinjauan pustaka yang relevan dan pengembangan hipotesis (jikaada) dimasukkan dalam bagian ini. (Times New Roman, 12, normal dan 1,5 spasi ).

\section{Metode Penelitian}

Usaha Mikro, Kecil dan Menengah (UMKM) dan Industri perbankan syariah di Indonesia adalah objek dalam penelitian ini. Penelitian dilakukan dengan menggunakan data sekunder, periode bulanan tahun 2016-2019. Data diperoleh dari Bank Indonesia, Biro Pusat Statistik dan Otoritas Jasa Keuangan. Aktivitas bank syariah ditelaah melalui pembiayaan yang disalurkan pada UMKM, yang diperkirakan memberikan dampak pada keuntungan bank dan meningkatkat aktivitas perekonomian secara makro di Indonesia.

Analisis penelitian menggunakan metode kualitatif dan kuantitatif, dilakukan berbagai uji statistik dan ekonometrik untuk memperoleh kesimpulan penelitian. Model analisis dalam penelitian ini menggunakan teknik estimasi panel simultan dengan 
270 | Iwan Setiawan, PEMBIAYAAN UMKM, KINERJA BANK SYARIAH DAN PERTUMBUHAN......

menggunakan metode Two Stage Least Square (TSLS) yang relevan untuk penelitian social.

Persamaan struktural model penelitian yang digunakan disajikan sebagai berikut ;

$R O A_{t}=\alpha_{0}+\alpha_{1} D P K_{t}+\alpha_{2} C A R_{t}+\alpha_{3} U M K M_{t}+\alpha_{4} S B I_{t}+\alpha I N F_{t}+\alpha_{6} \mathrm{GRW}+\varepsilon_{1} .(1)$

$G R W_{t}=\beta_{0}+\beta_{1} D P K_{t}+\beta_{2} C A R_{t}+\beta_{3} U M K M_{t}+\beta_{4} S B I_{t}+\beta_{5} I N F_{t}+\beta_{6} \mathrm{ROA}+\varepsilon_{2} \cdot$ (2)

Dimana :

ROA = Keuntungan bank syariah

GRW = Pertumbuhan ekonomi

DPK = Dana pihak ketiga pada perbankan syariah

CAR $=$ Modal pada bank syariah

$\mathrm{UMKM}=$ Pembiayaan bank syariah pada UMKM

SBI = Instrumen Sertifikat Bank Indonesia Syariah

INF $=$ Tingkat inflasi

Pada model penelitian, akan dilakukan berbagai uji hipotesis, statistik dan ekonometrika. Rancangan uji hipotesis untuk mengetahui rentabilitas dan pertumbuhan ekonomi melalui pengaruh kondisi internal bank syariah, intrumen kebijakan dan kondisi perekonomian secara makro.

\section{Pembahasan}

Berdasarkan proses pengolahan data, hasil Model Keuntungan Bank dan Model Pertumbuhan Ekonomi disajikan dalam tabel 1 sebagai berikut ;

Tabel 1

Hasil Pengolahan Data

Model Keuntungan Bank (ROA)

\begin{tabular}{|c|c|c|c|c|}
\hline Varabie & Coeffoent & sed End & LStanute & Path \\
\hline c & To275as & 202025 & -3.17085 & eoses \\
\hline an & onkex & 0 obtunt & 2207206 & ocosio \\
\hline DFE & 3 sesteto & contex & A17า & 0.0000 \\
\hline Lated & IEstath & 1screat & igrrst4 & 0,0025 \\
\hline NF & 4.96430 & 6006r9s & 6.500600 & 0.5001 \\
\hline sei & 0.023640 & Q.14500 & 0.36958 & 0.6704 \\
\hline GRW & 351090 & tescost & 1000303 & CDSOD \\
\hline A nequast & orsezas & \multicolumn{2}{|c|}{ Mean apendert var } & 100154 \\
\hline NGaled Rideane: & o.7mase & \multicolumn{2}{|c|}{ SD dependet $\alpha$} & asmist4 \\
\hline sf at ingusion & Q Q & \multirow{2}{*}{\multicolumn{2}{|c|}{ Nate int oterion }} & Astesth \\
\hline Sen wound nod & 1 Hesent & & & $000<59$ \\
\hline Log twillowe & Deекін & \multicolumn{2}{|c|}{ 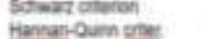 } & A 153687 \\
\hline Fitutste & 1018280 & \multirow{2}{*}{\multicolumn{2}{|c|}{ Dute- Watusen idx }} & troves \\
\hline Booff-statitio? & 0.000000 & & & \\
\hline
\end{tabular}

Sumber: Hasil pengolahan
Model Pertumbuhan Ekonemi (GRW)

\begin{tabular}{|c|c|c|c|c|}
\hline Varatie & Cueflicent & side Enot & SSutaste & Prob. \\
\hline c & 4 SEssas & 1.723506 & 2651431 & 00117 \\
\hline ROA & 0022920 & $0.01273 t$ & 1 acooss & 00080 \\
\hline caA & $\$ 007242$ & 0.004295 & -1684773 & 0.1008 \\
\hline UNexa & a. 1235 & 0.160996 & a roaOrs & 04833 \\
\hline NFF & is 520864 & $0.425 e n$ & 3 solses & 0.0010 \\
\hline Sहi & 0.025402 & a 010852 & 231345 & 000260 \\
\hline DPX & o. $094 \pi 24$ & 0.09776 & 1009602 & 63191 \\
\hline Rigared & 0 sonoses & \multicolumn{2}{|c|}{ Mean dependent yrm } & 1476295 \\
\hline Adjusied R aquared & $09+9805$ & \multicolumn{2}{|c|}{ SD dependent va } & Dosese? \\
\hline SE d tepression & 0.015968 & \multicolumn{2}{|c|}{ Maiks into onenon } & 5291554 \\
\hline Sum squared resit & o. oosuse & \multicolumn{2}{|c|}{ Sctwang critrion } & soonoe \\
\hline Log inzitiood & 1234142 & \multicolumn{2}{|c|}{ Harnop oum cret. } & S 166290 \\
\hline Fsentatic & A3 tyese & \multirow{2}{*}{\multicolumn{2}{|c|}{ Durbin Watson sta }} & ostoses \\
\hline Propif-seatates & 0.000000 & & & \\
\hline
\end{tabular}

E-ISSN : 2686-5149 
Hasil estimasi model Keuntungan Bank menunjukan nilai koefisien determinan (Adjusted $\mathrm{R}^{2}$ ) sebesar 0,717. Model dianggap mampu menjelaskan semua perubahan variabel independen terhadap perubahan variabel dependen. Nilai F statistik tinggi sebesar19,19 yang menunjukan nilai variabel independen secara bersama signifikan mempengaruhi variabel dependen. Hasil uji t, variabel modal bank syariah (CAR), dana pihak ketiga (DPK), pembiayaan bank syariah pada UMKM dan pertumbuhan ekonomi (GRW) memberikan pengaruh yang signifikan terhadap keuntungan bank syariah (ROA). Hasil estimasi model Pertumbuhan Ekonomi menunjukan nilai koefisien determinan (Adjusted $\mathrm{R}^{2}$ ) sebesar 0,92. Model dianggap mampu menjelaskan semua perubahan variabel independen terhadap perubahan variabel dependen. Nilai F statistik tinggi sebesar 83,2 yang menunjukan variabel independen secara bersama signifikan mempengaruhi pertumbuhan ekonomi. Hasil uji t, variabel keuntungan bank (ROA), modal bank (CAR), tingkat inflasi (INF) dan instrumen kebijakan moneter syariah (SBI) pengaruh signifikan terhadap pertumbuhan ekonomi (GRW) di Indonesia. Uji F dan uji t dilakukan pada taraf keyakinan $95 \%$ dan $99 \%$.

Hasil estimasi parameter model Keutungan Bank mengungkapkan bahwa terdapat 4 variabel independent, yaitu modal bank (CAR), dana pihak ketiga (DPK), pembiayaan (UMKM) dan pertumbuhan ekonomi (GRW) yang signifikan mempengaruhi keuntungan bank (ROA). Variabel modal bank (CAR) memperlihatkan koefisien regresi sebesar 0,11 yang berarti peningkatan $1 \%$ modal bank berpotensi meningkatkan keuntungan bank sebesar 0,11\%. Pengaruhnya kecil, termasuk katagori in-elastis, tetapi keberadaan modal bank merupakan variabel yang menentukan tingkat keuntungan bagi bank syariah. Variabel dana pihak ketiga (DPK) menunjukan nilai koefisien regresi sebesar -3,456 yang berarti peningkatan $1 \%$ simpanan dari masyarakat pada bank syariah berpotensi mengurangi keuntungan perbankan syariah sebesar 3,456 persen. Dana pihak ketiga berperan cukup besar, katagori elastis dalam menentukan keuntungan bagi bank syariah.

Variabel pembiayaan bank syariah untuk UMKM menunjukan koefisien regresi sebesar 3,66 yang berarti peningkatan $1 \%$ pembiayaan pada UMKM berpotensi 


\section{2 | Iwan Setiawan, PEMBIAYAAN UMKM, KINERJA BANK SYARIAH DAN PERTUMBUHAN......}

meningkatkan keuntungan bank sebesar 3,66\%. Pengaruhnya besar, termasuk katagori elastis, pelaksanaan pembiayaan bank syariah pada UMKM sangat menentukan tingkat keuntungan bagi bank syariah. Variabel pertumbuhan ekonomi (GRW) menunjukan nilai koefisien regresi sebesar 3,51 yang berarti peningkatan $1 \%$ pertumbuhan ekonomi berpotensi meningkatakan keuntungan bagi bank syariah sebesar 3,51 persen. Pertumbuhan ekonomi berperan besar, termasuk katagori elastis, dalam menentukan keuntungan bagi bank syariah.

Hasil estimasi parameter model Pertumbuhan Ekonomi mengungkapkan bahwa terdapat 4 variabel independent, yaitu keuntungan bank (ROA), modal bank (CAR), tingkat inflasi (INF), dan instrumen kebijakan moneter syariah (SBI) yang mempengaruhi pertumbuhan ekonomi (GRW). Variabel keuntungan bank (ROA) memperlihatkan koefisien regresi sebesar 0,02 yang berarti peningkatan $1 \%$ keuntungan bank syariah berpotensi meningkatkan pertumbuhan ekonomi 0,02\%. Pengaruhnya kecil, katagori in-elatis, tetapi keuntungan bank syariah merupakan salah satu faktor yang berpengaruh terhadap pertumbuhan ekonomi di Indonesia. Variabel Modal pada bank syariah (CAR) memperlihatkan koefisien regresi sebesar -0,007 yang berarti peningkatan $1 \%$ modal bank syariah berpotensi menurunkan pertumbuhan ekonomi sebesar 0,007 persen. Pengaruhnya kecil, katagori in-elastis, tetapi modal bank syariah merupakan salah variabel berpengaruh terhadap pertumbuhan ekonomi.

Variabel tingkat inflasi (INF) menujukan koefisien regresi sebesar 1,53 yang berarti peningkatan $1 \%$ inflasi berpotensi mendorong pertumbuhan ekonomi di Indonesia 1,53 persen. Inflasi berperan cukup besar, katagori elastis, dalam menentukan pertumbuhan ekonomi di Indonesia. Variabel instrumen kebijakan moneter syariah (SBI) menunjukan koefisien regresi sebesar 0,025 yang berarti peningkatan $1 \%$ dari nilai instrumen kebijakan moneter syariah berpotensi menimgkatkan pertumbuhan ekonomi Indonesia sebesar 0,025\%. Instrumen kebijakan moneter syariah perannya kecil, katagori in-elastis, dalam menentukan pertumbuhan ekonomi di Indonesia.

Secara umum hubungan antar variabel penelitian untuk model keuntungan bank (ROA) dan pertumbuhan ekonomi (GRW) disajikan dalam gambar berikut ini. 


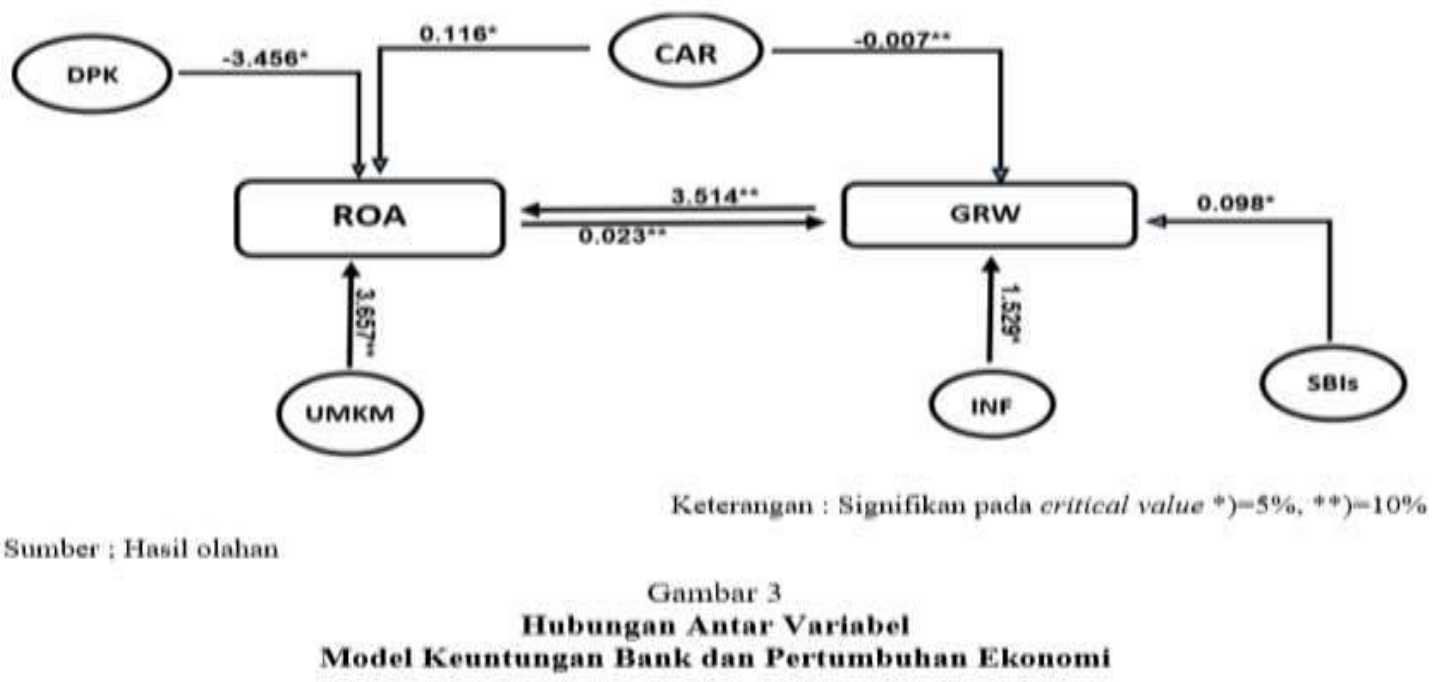

Melalui hubungan antar variabel dalam model Keuntungan Bank, terungkap bahwa peningkatan pembiayaan bank syariah pada UMKM, pertumbuhan ekonomi, penambahan modal bank dan menurunnya dana pihak ketiga dapat meningkatkan keuntungan pada bank syariah. Pembiayaan bank syariah yang tersalur untuk membiayai kegiatan UMKM pada berbagai skema memberikan kontribusi besar terhadap nilai keuntungan yang diperoleh pihak bank. Pembiayaan merupakan kegiatan utama lembaga keungan bank, kontribusinya besar terhadap peningkatan keuntungan bank. Peningkatan jumlah dan porsi pembiayaan UMKM mendorong peningkatan keuntungan bank syariah. Hasil penelitian ini sejalan dengan kajian lain yang mengungkapkan bahwa peningkatan rasio pembiayaan terhadap dana pihak ketiga (FDR) akan menambah keuntungan bank syariah (Zuwardi \& Padli, 2019) .

Pertumbuhan ekonomi identik dengan terjadinya peningkatan aktivitas ekonomi dan meningkatnya daya beli masyarakat serta menjadi aspek pendorong terjadinya investasi pada sektor UMKM. Investasi dengan memafaatkan dana pembiayaan menjadi faktor penyebab meningkatnya keuntungan bank Syariah. Modal bank berperan sebagai penyangga supaya bank dapat melakukan pembiayaan secara optimal kenapa nasabahnya. Modal bank pengaruhnya sangat kecil terhadap peningkatan keuntungan. Dana pihak ketiga memberikan kontribusi negatif terhadap keuntungan bank. Peningkatan dana simpanan masyarakat menimbulkan beban biaya tambahan jika bank 


\section{4 | Iwan Setiawan, PEMBIAYAAN UMKM, KINERJA BANK SYARIAH DAN PERTUMBUHAN......}

syariah tidak mampu mengalokasikan pada aset produktif dan menguntungkan. Peningkatan dana pihak ketiga berpotensi mengurangi keuntungan yang dapat diperoleh bank syariah di Indonesia. Hasil penelitian ini sejalan dengan penelitian lain yang mengungkap bahwa peningkatan modal meningkatkan potensi keuntungan, tapi peningkatan pembiayaan bermasalah akibat dari pemanfaatan dana pihak ketiga yang kurang berhati-hati mengakibatkan berkurangnya keuntungan bank syariah (Tho'in, 2019).

Melalui hubungan antar variabel dalam model pertumbuhan ekonomi, terungkap bahwa peningkatan keuntungan bank syariah, peningkatan inflasi, peningkatan suku bunga/keuntungan pada instrumen kebijakan moneter syariah dan menurunnya modal bank syariah dapat meningkatkan pertumbuhan ekonomi. Keuntungan bank syariah (ROA), walaupun tidak besar nilainya, memberikan kontribusi terhadap pertumbuhan ekonomi di Indonesia. Setiap peningkatan keuntungan bank syariah menggambarkan terjadinya peningkatan nilai tambah proses pembiayaan dan aktivitas ekonomi sehingga dapat mendorong terjadinya pertumbuhan ekonomi. Inflasi diprediksi terjadi akibat meningkatnya sisi permintaan dan daya beli sehingga akan mendorong terjadinya pertumbuhan ekonomi. Bank Syariah masih memanfaatkan intrumen pasar keuangan syariah sebagai alternatif alokasi pembiayaan dan memberikan tambahan keuntungan bagi pihak bank. Setiap kenaikan insentif dari instrumen kebijakan moneter syariah akan menambah keuntungan bagi pihak bank syariah.

Modal bank syariah merupakan salah satu variabel yang berpengaruh signifikan terhadap pertumbuhan ekonomi. Ditemukah hubungan tidak searah antara peningkatan modal dan pertumbuhan ekonomi. Peningkatan modal berakibat pada menurunnya pertumbuhan ekonomi. Peningkatan modal berpotensi menambah pembiayaan bank. Dua kemungkinan hasil proses pembiayaan yang dilakukan bank syariah. Pertama pembiayaan berhasil, meningkatkan keuntungan bagi pihak bank dan nasabah sehingga mendorong pertumbuhan ekonomi. Kemungkinan kedua adalah terjadinya pembiayaan yang gagal, mengurangi keuntungan bagi nasabah dan bank sehingga mengakibatkan menurunnya pertumbuhan ekonomi. Ketidak mampuan bank syariah melakukan 
pembiayaan berkualitas menjadi faktor penyebab hubungan negatif antara modal dan petunbuhan ekonomi.

Pembiayaan bank syariah pada UMKM memberikan konstribusi yang besar terhadap kinerja bank syariah yang diukur dengan nilai ROA (rentability of asset). Setiap satu persen kenaikan pembiayaan akan berkribusi sebesar 3,65 persen peningkatan keuntungan bank syariah. Pembiayaan UMKM bank syariah tidak memberi kontribusi terhadap peningkatan pertumbuhan ekonomi untuk hubungan bersifat langsung. Kontribusi pembiayaan UMKM terhadap pertumbuhan ekonomi terjadi melalui peran keuntungan (ROA) bank syariah. Peran keuntungan bank syariah terhadap pertumbuhan ekonomi kecil, setiap peningkatan satu persen keuntungan bank syariah hanya berkontribusi sebesar 0,023 persen terhadap pertumbuhan ekonomi. Terdapat hubungan dua arah dan saling mempengaruhi antara keuntungan bank syariah dengan pertumbuhan ekonomi. Peran perrtumbuhan ekonomi terhadap keuntungan bank lebih besar dari pada peran keuntungan bank syariah terhadap pertumbuhan ekonomi.

Usaha memperbaiki kualitas UMKM sejalan dengan upaya untuk meningkatkan kinerja bank syariah dan akan mendorong pertumbuhan ekonomi. Peningkatan jumlah dan porsi pembiayaan pada UMKM yang disertai dengan perbaikan kualitasnya, akan memdorong peningkatan kinerja bank syariah. Hubungan pembiayaan terhadap pertumbuhan ekonomi bersifat tidak langsung melalui perantara kinerja bank. Peningkatan kinerja bank akibat dari peningkatan jumlah, porsi dan kualitas pembiayaan pada UMKM akan mendorong pertumbuhan ekonomi. Sangat penting memperhatikan kualitas dan jumlah pembiayaan pada UMKM untuk meningkatkan kinerja (keuntungan bank syariah) dan pertumbuhan ekonomi di Indonesia. 


\section{6 | Iwan Setiawan, PEMBIAYAAN UMKM, KINERJA BANK SYARIAH DAN PERTUMBUHAN......}

\section{Simpulan}

Pembiayaan pada UMKM memberikan kontribusi yang besar terhadap peningkatan kinerja bank bank syariah. Peran pembiayaan UMKM sudah sesuai dengan peran utama bank syariah sebagai lembaga perantara keuangan, menghimpun dana dari masyarakat dan menyalurkan dalam bentuk pembiayaan. Pembiayaan yang merupakan aset utama dari perbankan syariah memberikan kontribusi besar terhadap peningkatan keuntungan pada bank syariah. Modal bank, dana pihak ketiga dan pertumbuhan ekonomi merupakan variabel lain yang memberikan peran terhadap perubahan kinerja keuntungan bank syariah. Modal dan pertumbuhan ekonomi memberikan peran positif terhadap keutungan bank syariah. Dana pihak ketiga (DPK) memberikan peran negatif terhadap keuntungan bank syariah. Pemanfaatan dana pihak ketiga tidak sejalan dengan jumlah dana yang tersalur, terjadi penurunan porsi rasio pembiayaan terhadap dana pihak ketiga (FDR), sehingga setiap peningkatan dana pihak ketiga menimbulkan beban tambahan yang akan mengurangi tingkat keuntungan bank syariah.

Pembiayaan UMKM bank syariah tidak memberi kontribusi terhadap peningkatan pertumbuhan ekonomi. Kontribusi pembiayaan UMKM terhadap pertumbuhan ekonomi terjadi melalui peran keuntungan (ROA) bank syariah. Peran keuntungan bank syariah terhadap pertumbuhan ekonomi kecil. Peningkatan keuntungan bank syariah berkontribusi rendah terhadap pertumbuhan ekonomi. Terdapat hubungan dua arah dan saling mempengaruhi antara keuntungan bank syariah dengan pertumbuhan ekonomi. Peran pertumbuhan ekonomi terhadap keuntungan bank lebih besar dari pada peran keuntungan bank syariah terhadap pertumbuhan ekonomi. Modal bank, intrumen kebijakan moneter syariah dan inflasi merupakan variabel lain yang berperang terhadap pertumbuhan ekonomi di Indonesia. Modal bank berpengaruh negatif, instrumen kebijakan moneter syariah dan inflasi menberilkan pengaruh positif terhadap pertumbuhan ekonomi di Indonesia.

Usaha memperbaiki kualitas UMKM sejalan dengan upaya untuk meningkatkan kinerja bank syariah dan akan mendorong pertumbuhan ekonomi. Peningkatan jumlah dan porsi pembiayaan pada UMKM yang disertai dengan perbaikan kualitasnya, akan memdorong peningkatan kinerja keuntungan bank syariah. Hubungan pembiayaan P-ISSN : 2460-9595 
terhadap pertumbuhan ekonomi bersifat tidak langsung melalui perantara kinerja bank. Peningkatan kinerja bank akibat dari peningkatan jumlah, porsi dan kualitas pembiayaan pada UMKM akan mendorong pertumbuhan ekonomi. Sangat penting memperhatikan kualitas dan jumlah pembiayaan pada UMKM untuk meningkatkan kinerja (keuntungan bank syariah) dan pertumbuhan ekonomi di Indonesia.

\section{DAFTAR PUSTAKA}

Afkar, T. (2017). Pengaruh Pembiayaan Usaha Mikro, Kecil, Menengah (Umkm), Dan Kecukupan Modal Terhadap Kemampuan Mendapatkan Laba Dari Aset Perbankan Syariah Di Indonesia. Al-Uqud: Journal of Islamic Economics, 1(2), 183. https://doi.org/10.26740/jie.v1n2.p183-201

Afkar, T., Utomo, S. P., Miradji, M. A., \& Hariawan, F. (2020). The Role Of ProfitLoss Sharing In Development Of Msmes. International Journal of Economics, Business and Accounting Research (IJEBAR), 4(1), 173-184.

Darsono, D., \& Darwanto, D. (2019). Strengthening the MSME Through Institutional Cooperation Improvement Between MSME and Sharia Microfinance Institutions $\begin{array}{lllll}\text { (SMFI). Jurnal Ilmiah Al-Syir'ah, } & \text { 17(1), }\end{array}$ https://doi.org/10.30984/jis.v17i1.809

El Ayyubi, S., Anggraeni, L., \& Mahiswari, A. D. (2018). Pengaruh Bank Syariah terhadap Pertumbuhan Ekonomi di Indonesia. Al-Muzara'ah, 5(2), 88-106. https://doi.org/10.29244/jam.5.2.88-106

Faisol, F. (2017). Islamic Bank Financing and It's Impact on Small Medium Enterprise's Performance. Etikonomi, 16(1), 13-24. https://doi.org/10.15408/etk.v16i1.4404

Hamza, L. M., \& Agustien, D. (2019). Pengaruh Perkembangan Usaha Mikro, Kecil, dan Menengah Terhadap Pendapatan Nasional Pada Sektor UMKM di Indonesia. Jurnal Ekonomi Pembangunan, 8(2), 127-135. https://doi.org/10.23960/jep.v8i2.45

Kara, M. (2013). Konstribusi Pembiayaan Perbankan Syariah Terhadap Pengembangan Usaha Mikro Kecil Dan Menengah (Umkm) Di Kota Makassar. Ilmu Syariah Dan Hukum, 47(1), 315-322.

Kasri, R. A., \& Azzahra, C. (2020). Do Islamic banks more stable than conventional banks? Evidence from Indonesia. Jurnal Ekononomi \& Keuangan Islam, 6(2), 149-164. https://doi.org/10.20885/JEKI.vol6.iss1.art5

Lubis, D. S. (2016). Pemberdayaan UMKM Melalui Lembaga Keuangan Syariah 
278 I Iwan Setiawan, PEMBIAYAAN UMKM, KINERJA BANK SYARIAH DAN PERTUMBUHAN......

Sebagai Upaya Pengentasan Kemiskinan Kota Padangsidimpuan. At-Tijaroh, 2(2), 270-285.

Nurhidayat. (2020). Pendekatan Ekonomi Syariah Dalam Menyelesaikan Masalah Ekonomi Akibat Pandemi COVID-19. ISLAMIC BANKING ; Jurnal Pemikiran Dan Pengembangan Perbankan Syariah, 6(1), 17-34.

Qoyum, A., \& Fauziyyah, N. E. (2019). The Halal Aspect And Islamic Financing Among Micro, Small, And Medium Enterpises (Msmes) In Yogyakarta: Does Berkah Matter? Journal of Islamic Monetary Economics and Finance, 5(1), 215-236. https://doi.org/10.21098/jimf.v5i1.1055

Sahyouni, A., \& Wang, M. (2018). The Determinants of Bank Profitability: Does Liquidity Creation Matter? In SSRN Electronic Journal. https://doi.org/10.2139/ssrn.3125714

Setiawan, I. (2017). Peran Perbankan Syariah Terhadap Perekonomian di Indonesia (Pendekatan Model VAR/VECM). Tedc, 11(2), 172-178.

Setiawan, I. (2019). The Role of Islamic Banking in the Development of Economic Sectors in Indonesia. International Journal of Applied Business Research, 1(02), 88-99. https://doi.org/10.35313/ijabr.v1i02.70

Setiawan, I. (2020). Analisis Peran Perbankan terhadap Pertumbuhan Ekonomi di Indonesia: Bank Syariah Versus Bank Konvensional. JURNAL AKUNTANSI, EKONOMI Dan MANAJEMEN BISNIS, 8(1), 52-60. https://doi.org/10.30871/jaemb.v8i1.1649

Tambunan, T. (2019). Recent evidence of the development of micro, small and medium enterprises in Indonesia. Journal of Global Entrepreneurship Research, 9(1). https://doi.org/10.1186/s40497-018-0140-4

Tho'in, M. (2019). Profitability of Islamic Commercial Banks In Indonesia. Iqtishadia: Jurnal Ekonomi Dan Perbankan Syariah, 6(2), 89-99. https://doi.org/10.19105/iqtishadia.v6i2

Trimulato, T. (2017). Analisis Potensi Produk Musyarakah Terhadap Pembiayaan Sektor Riil Umkm. Jurnal Ekonomi \& Studi Pembangunan, 18(1), 41-51. https://doi.org/10.18196/jesp.18.1.3830

Zaimsyah, A. M. (2020). Factors Affecting the Distribution of Micro, Small and Medium Enterprises (MSME) Financing in Islamic Banks. AL-FALAH : Journal of Islamic Economics, 5(1), 38. https://doi.org/10.29240/alfalah.v5i1.1156

Zuwardi, \& Padli, H. (2019). Determinan Profitabilitas Bank Umum Syariah. Jurnal Ilmu Manajemen Dan Bisnis Islam, 5, 201-215. https://doi.org/ISSN: 2549-9270 